CLINICAL STUDY

\title{
Clinical use of cabergoline as primary and adjunctive treatment for acromegaly
}

\author{
V J Moyes, K A Metcalfe ${ }^{1}$ and W M Drake \\ Department of Endocrinology, King George V Wing, St Bartholomew's Hospital, West Smithfield, London EC1A 7 BE, UK and ${ }^{1}$ Department of \\ Endocrinology, Southend Hospital, Southend-on-Sea, UK
}

(Correspondence should be addressed to W M Drake; Email: w.m.drake@qmul.ac.uk)

\begin{abstract}
Background: Cabergoline is a dopamine agonist that may be used as primary or adjunctive therapy for acromegaly. Although one study suggested biochemical control may be achieved in a substantial proportion of patients, it is still commonly perceived to be a relatively ineffective treatment.

Design and method: A prospective audit was performed of 15 consecutive acromegalic patients (eight males, seven females, median age 55, range 31-92 at presentation) treated with cabergoline to determine the effective dose and tolerability. All had normal anterior pituitary function; two patients had hyperprolactinaemia. Magnetic resonance imaging revealed nine adenomata, two partially empty sellae and four structurally normal pituitary glands. Nine patients had undergone transsphenoidal surgery 1-12 months, and one patient had received pituitary radiotherapy 18 years, prior to commencement of cabergoline. All patients had biochemical GH excess; median serum IGF1 $471 \mathrm{ng} / \mathrm{ml}$, range $239-746 \mathrm{ng} / \mathrm{ml}$. The calculated mean of a series of GH measurements ranged from 2.7-45.8 mIU/l, median $9.7 \mathrm{mIU} / \mathrm{l}$.

Results: On a median weekly dose of cabergoline of $1.75 \mathrm{mg}$ (range $0.5-7 \mathrm{mg}$ ) normalisation of both IGF1 and GH occurred in 4 out of the 15 patients (27\%). Out of the 15 patients (33\%), 5 achieved a serum IGF1 within the reference range with notable reductions seen in a further five patients. Nine patients $(60 \%)$ achieved a mean serum GH level of less than $5 \mathrm{mIU} / \mathrm{l}$. Duration of treatment was 2-52 months and was well tolerated in 14 patients.

Conclusion: Cabergoline can be an effective and well tolerated primary or adjunctive therapy for acromegaly and useful clinical responses are noted even with modest doses.
\end{abstract}

European Journal of Endocrinology 159 541-545

\section{Introduction}

Uncontrolled acromegaly is associated with increased morbidity and mortality; excess adjusted mortality rates are increased between 1.9 and 3.3 fold (1-3) while a reduction of circulating growth hormone $(\mathrm{GH})$ to a 'safe' level of $<5 \mathrm{mIU} / \mathrm{l}$ has been demonstrated to normalise mortality rates (3). Multiple therapeutic approaches, including pituitary surgery, external pituitary irradiation and medical therapy are often needed to achieve an acceptable level of GH control. In experienced surgical hands, $60 \%$ of patients may be cured by pituitary surgery alone where strict biochemical criteria are used (4-7) although success rates are significantly lower in patients with macroadenoma and are dependent on surgical expertise. Adjunctive therapeutic options are therefore necessary for a significant proportion of patients in order to normalise GH and insulin-like growth factor-1 (IGF1) production. Repeated attempts at pituitary surgery may be associated with increased morbidity and risk of hypopituitarism, and are unlikely to provide a cure (8). External beam pituitary radiotherapy is effective but is characterised by delayed action and a significant risk of hypopituitarism (9). Three medical options exist: dopamine agonists (DAs), somatostatin analogues, and pegvisomant. Somatostatin analogues result in normalisation of GH secretion and IGF1 production in 45-65\% of patients $(10,11)$ but require a parenteral route of administration and may be associated with adverse effects including local inflammation, gastrointestinal symptoms and cholelithiasis. Pegvisomant, a GH receptor antagonist, is very effective, with normalisation of IGF 1 in $97 \%$ of patients $(12,13)$ but its use is limited by cost, availability and the requirement for daily s.c. injections.

Cabergoline is an ergot-derived DA, selective for the D2 receptor with a longer half-life and improved tolerability compared with other DAs such as bromocriptine. Its oral administration and relative inexpense make it a potentially attractive option for the medical treatment of acromegaly. Several reports exist on the use of cabergoline in acromegaly, with conflicting results. In the largest of these (14) a reduction of serum IGF1 to $<300 \mathrm{ng} / \mathrm{ml}$ was achieved in $\sim 40 \%$ of 
patients, yet the drug is still commonly perceived to be a relatively ineffective treatment, possibly on account of inadequate dosing. Here, we report data from a prospective audit of 15 consecutive acromegalic patients in order to determine the effectiveness, doses required, and tolerability of cabergoline in routine clinical practice.

\section{Subjects and methods}

It is the authors' prescribing policy to use oral cabergoline as first-line therapy for patients with persistent active acromegaly following attempted transsphenoidal adenomectomy, or in those patients who are unwilling or unfit to undergo surgery. Against this background, the cohort reported in this audit consisted of eight males and seven females, aged 31-92 at presentation (Table 1). The diagnosis of acromegaly was confirmed by a failure to suppress $\mathrm{GH}$ levels on a standard glucose tolerance test; nadir GH level ranged between 4.4 and $159.0 \mathrm{mIU} / \mathrm{l}$ with a median of $18.0 \mathrm{mIU} / \mathrm{l}$. Median serum IGF1 was $721 \mathrm{ng} / \mathrm{ml}$ (median SDS + 10.2) with a range $285-1087 \mathrm{ng} / \mathrm{ml}$ (SDS +1.6 to +29.4$)$. Pituitary adenomata were identified in nine patients; seven were macroadenoma. Two patients had partially empty sellae and four had structurally normal pituitary glands. Anterior pituitary function was normal in all patients at diagnosis. Hyperprolactinaemia was identified in two patients (serum prolactin 1187 and $1254 \mathrm{mIU} / \mathrm{l}$ (normal range $0-450$ ).

Five patients who were unwilling or medically unfit to undergo pituitary surgery commenced cabergoline as primary treatment for acromegaly. Nine patients had undergone non-curative transsphenoidal surgery 1-12 months prior to commencement of cabergoline. Two had received external beam radiotherapy, one as primary treatment 18 years previously and one as an adjunct to pituitary surgery 3 months prior to commencing cabergoline. Histological examination of resected pituitary glands revealed GH immunostaining in five patients and coexpression of $\mathrm{GH}$ and prolactin in two patients. All patients had biochemical GH excess at the time of commencement of cabergoline, judged by the mean of several samples taken through the day (a GH day curve). The median value of these calculated 'day curve means' was $9.7 \mathrm{mIU} / \mathrm{l}$, range $2.7-45.8 \mathrm{mIU} / \mathrm{l}$. Median serum IGF1 was $471 \mathrm{ng} / \mathrm{ml}$ (SDS + 7.61), with a range of $239-746 \mathrm{ng} / \mathrm{ml}$ (SDS + 1.6 to +18.7 ).

All patients were treated with cabergoline as the sole medical therapy. Starting weekly doses ranged from 0.5 to $1 \mathrm{mg}$ /week and doses were titrated according to the clinical and biochemical response and tolerability.

The effectiveness of cabergoline was assessed by the reduction in IGF1 and mean GH levels on treatment. Mean GH results were unavailable in one patient who has since commenced a somatostatin analogue. Complete biochemical remission was considered to have been achieved if the mean GH was $<5 \mathrm{mIU} / \mathrm{l}$ in association with a normal age-related serum IGF 1 level. IGF1 levels are expressed as absolute values and as SDS calculated from normative serum IGF1 data provided by Siemens Medical Solutions Diagnostics (Gwynedd, Wales, UK) (based on 840 healthy volunteers). Normal IGF1 SDS are defined as -2 to +2 .

The study received institutional board approval as a prospective audit.

\section{Assays}

Serum IGF1 was measured by an automated solidphase, enzyme-labelled chemiluminescent immunometric assay (Siemens Medical Solutions Diagnostics), with intra- and interassay coefficients of variation (CV)

Table 1 Clinical details and demographics of the cohort studied.

\begin{tabular}{|c|c|c|c|c|c|c|c|c|}
\hline \multirow[b]{2}{*}{ Pt } & \multirow[b]{2}{*}{ Age } & \multirow[b]{2}{*}{ Sex } & \multirow[b]{2}{*}{ MRI } & \multirow[b]{2}{*}{ Previous Rx } & \multirow[b]{2}{*}{ Histology } & \multicolumn{3}{|c|}{ At diagnosis } \\
\hline & & & & & & Mean GH (mIU/l) & $\begin{array}{l}\text { IGF1 } \\
\text { (ng/ml) }\end{array}$ & PRL (mlU/l) \\
\hline 1 & 65 & $\mathrm{~F}$ & Empty sella & Nil & l & 18.5 & 722 & 182 \\
\hline 2 & 74 & $\mathrm{M}$ & Normal & Nil & l & 9.7 & 421 & 161 \\
\hline 3 & 52 & $\mathrm{~F}$ & Empty sella & RT $1983, S^{a}$ & I & 41.5 & 602 & 'Normal' \\
\hline 4 & 31 & $\mathrm{~F}$ & Macroadenoma & TSS Feb 2006, RT & GH & 40.8 & 733 & 378 \\
\hline 5 & 92 & $\mathrm{~F}$ & Normal & Nil & I & 39.0 & 528 & 491 \\
\hline 6 & 61 & $\mathrm{M}$ & Normal & Nil & 1 & 7.8 & 736 & 248 \\
\hline 7 & 63 & $\mathrm{M}$ & Normal & Nil & I & 7.4 & 285 & 141 \\
\hline 8 & 62 & $\mathrm{M}$ & Macroadenoma & TSS May 2004 & $\mathrm{GH}$ & 14.6 & 739 & 332 \\
\hline 9 & 44 & $\mathrm{M}$ & Microadenoma & TSS May 2005 & GH & 6.4 & 585 & 518 \\
\hline 10 & 69 & $\mathrm{~F}$ & Macroadenoma & TSS Feb 2007 & GH & 17.8 & 488 & 204 \\
\hline 11 & 55 & $\mathrm{~F}$ & Microadenoma & TSS Jan 2006 & $\mathrm{GH} / \mathrm{PRL}$ & 62.0 & 900 & 1187 \\
\hline 12 & 53 & $\mathrm{M}$ & Macroadenoma & TSS Feb 2007 & GH & 78.0 & 721 & 205 \\
\hline 13 & 40 & $\mathrm{~F}$ & Macroadenoma & TSS Jul 2006 & $\mathrm{GH}$ & 116.8 & 816 & 343 \\
\hline 14 & 36 & M & Macroadenoma & TSS Jan 2008 & GH & 158 & 1087 & 187 \\
\hline 15 & 35 & $\mathrm{M}$ & Macroadenoma & TSS Aug 2007 & $\mathrm{GH} / \mathrm{PRL}$ & 47.1 & 926 & 1254 \\
\hline
\end{tabular}

RT, external beam radiotherapy; TSS, transsphenoidal surgery; SA, somatostatin analogue. ${ }^{a}$ Not tolerated. 
of less than $11 \%$ and less than $8 \%$ respectively. Serum GH was quantitated by an IRMA using Immulite 2000 (Siemens Medical Solutions Diagnostics), with interand intraassay $\mathrm{CVs}$ of $5 \%$.

\section{Results}

Out of the 15 patients (27\%), 4 demonstrated complete biochemical remission of acromegaly with normalisation of IGF1 and a mean GH of $<5 \mathrm{mIU} / \mathrm{l}$ (Table 2). Mean GH levels of $<5 \mathrm{mIU} / \mathrm{l}$ were noted in 9 out of 14 patients $(64 \%)$ in total, with modest reductions in a further 3 .

Out of the 15 patients (33\%), 5 achieved a serum IGF1 level within the normal reference range (SDS -2 to +2 ) with notable reductions evident in a further 5 (33\%) patients (achieving IGF1 SDS of +2.11 to $+13.15)$. In 5 out of 15 (33\%) patients, it was judged that there was no clinically useful reduction in serum IGF1 levels (Fig. 1, Fig. 2).

Out of 13 patients $(40 \%), 6$ demonstrated discordance between IGF1 and GH levels, with a safe mean GH level $<5 \mathrm{mIU} / \mathrm{l}$ in association with a serum IGF1 above the age-adjusted reference range. This is well documented with discordance rates of 35\% reported (15); factors responsible for this discordance have not yet been determined. Out of the two patients with hyperprolactinaemia and prolactin immunostaining on histological review, there was no reduction in IGF1 in one patient and a fall of $22.6 \%$ (from 485 to $375 \mathrm{ng} / \mathrm{ml}$ ) in the other.

Median cabergoline dose was $1.75 \mathrm{mg}$ weekly (range 0.5-7) for a median of 6 months (range 2-48). Duration of treatment was 6 weeks to 48 months.
Clinical response was evident at the first routine clinical assessment, 6 weeks to 3 months post commencement. Out of the 15 patients, 14 tolerated cabergoline with no side effects, while one patient experienced unacceptable nausea and discontinued treatment after 8 weeks.

\section{Discussion}

DAs have been used for the treatment of acromegaly since the mid 1970s (16). This class of drug causes stimulation of GH release in normal individuals, but leads to paradoxical suppression of GH hypersecretion in a proportion of patients with acromegaly. Five subtypes of dopamine receptor exist, which have specific tissue distribution; D2 receptors are expressed in the anterior and intermediate lobes of the pituitary gland and mediate inhibition of prolactin secretion. The effectiveness of DAs in the control of $\mathrm{GH}$ secretion appears to correlate with expression of D2 receptors within the tumour rather than the presence of prolactin (17). Experience is greatest with bromocriptine; $~ 10 \%$ of patients achieve safe $\mathrm{GH}$ and normal age-adjusted IGF1 levels using doses substantially higher than those required for the successful treatment of prolactin secreting tumours. Similarly, disappointing data exist for pergolide and lysuride, although up to one-third of patients achieved biochemical control with the nonergot-derived DA quinagolide at doses two to three times those used in the treatment of prolactinomas (18).

Possibly as a result of clinical experience with early DAs and on account of the side effect profile associated with the large doses required to achieve a useful clinical effect (including gastrointestinal disturbances and postural hypotension), there is a widespread perception

Table 2 Summary of growth hormone and serum insulin-like growth factor-1 (IGF1) results and doses of cabergoline.

\begin{tabular}{|c|c|c|c|c|c|c|c|}
\hline \multirow[b]{3}{*}{ Pt } & \multirow{2}{*}{\multicolumn{2}{|c|}{ Mean GH (mIU/l) }} & \multicolumn{4}{|c|}{ Serum IGF1 (ng/ml) } & \multirow{3}{*}{$\begin{array}{c}\text { Dose of cabergoline } \\
\text { (mg/week) }\end{array}$} \\
\hline & & & \multicolumn{2}{|c|}{ Pre-cabergoline } & \multicolumn{2}{|c|}{ On cabergoline } & \\
\hline & Pre-cabergoline & On cabergoline & Result & SDS & Result & SDS & \\
\hline 1 & 18.5 & 2.6 & 722 & +9.90 & 132 & -1.38 & 7 \\
\hline 2 & 9.7 & 5.6 & 421 & +8.71 & 217 & +2.62 & 3.5 \\
\hline 3 & 9.9 & 6.4 & 602 & +7.61 & 276 & +1.37 & 3.5 \\
\hline 4 & 11.5 & 10.0 & 505 & +11.18 & 565 & +13 & 1.75 \\
\hline 5 & 38.9 & 9.9 & 528 & +6.20 & 336 & +2.52 & 5.25 \\
\hline 6 & 7.8 & $-^{a}$ & 736 & +10.16 & 762 & +10.66 & 1.5 \\
\hline 7 & 7.4 & 2.26 & 285 & +1.55 & 150 & -1.03 & 1.75 \\
\hline 8 & 14.6 & 1.2 & 471 & +5.10 & 157 & -0.9 & 3.5 \\
\hline 9 & 6.4 & 1.2 & 461 & +9.90 & 200 & +2.11 & 1.75 \\
\hline 10 & 10.9 & 3.1 & 305 & +1.93 & 228 & +0.45 & 1.75 \\
\hline 11 & 2.7 & 1.5 & 239 & +2.32 & 275 & +3.08 & 1.75 \\
\hline 12 & 3.3 & 3.9 & 301 & +3.63 & 310 & +3.82 & 0.5 \\
\hline 13 & 3.5 & 3.8 & 303 & +4.86 & 337 & +5.92 & 0.5 \\
\hline 14 & 13.7 & 14.8 & 746 & +18.72 & 568 & +13.15 & 1.0 \\
\hline 15 & 6.6 & 3.84 & 485 & +10.55 & 375 & +7.11 & 1.0 \\
\hline
\end{tabular}

This table summarises the biochemical data for the cohort before and after commencement on cabergoline. SDS are used to demonstrate the variation of serum IGF1 level from the normal reference range.

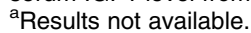




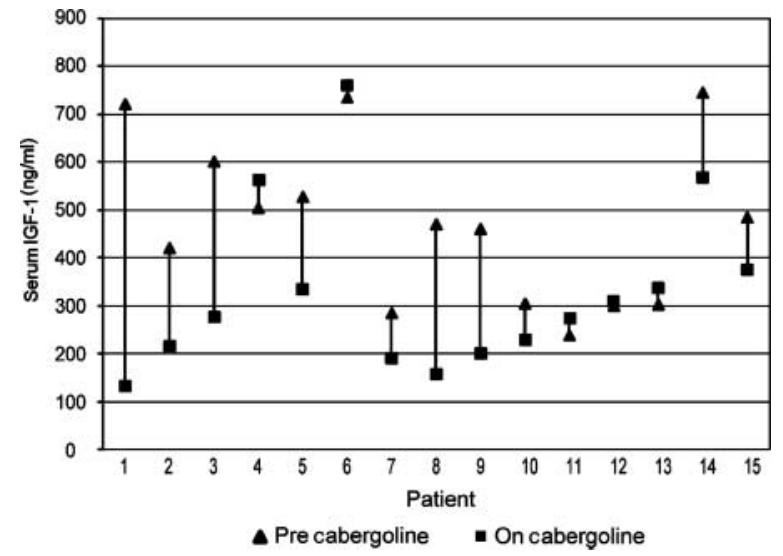

Figure 1 Changes in serum IGF1 levels in response to treatment with cabergoline in each patient studied.

that drugs of this class are ineffective in the treatment of acromegaly and that their use is largely ancillary. Cabergoline, also an ergot derivative, has greater specificity for the D2 receptor and a substantially longer half-life than bromocriptine, thereby leading to fewer fluctuations in DA activity, more prolonged action and fewer side effects. In the largest study to date, a normal serum IGF1 was achieved in 39\% of patients treated with up to $3.5 \mathrm{mg} /$ week (14). Prolactin cosecretion and milder disease activity were favourable predictors of a good response; $\sim 50 \%$ of patients achieved a serum IGF1 within the age-related reference range with starting value $<750 \mathrm{ng} / \mathrm{ml}$. In other, smaller, studies, the proportion of patients achieving satisfactory biochemical control on cabergoline alone has been variable, although clinical improvement and substantial reductions in GH/IGF1 levels were seen in the majority of patients (18-20). These reports, in part, have led to emerging literature on the use of cabergoline as an 'addon' therapy for patients incompletely responsive to injectable somatostatin analogues $(17,21)$. Normalisation of GH and IGF1 levels has been demonstrated in

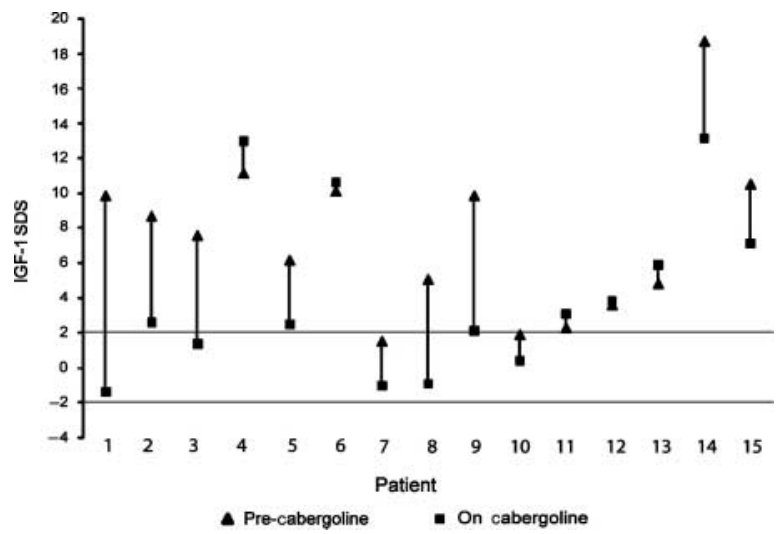

Figure 2 Changes in serum IGF1 standard deviation scores (SDS) in response to cabergoline treatment for each patient studied.
$44-47 \%$ of patients partially resistant to somatostatin analogues $(17,22)$.

For the $40 \%$ of patients not cured by transsphenoidal surgery, adjunctive treatment is required for control of $\mathrm{GH}$ excess. In recent years, the use of external beam radiotherapy has become less widespread, partly due to its delayed action and the significant risk of hypopituitarism; but also on account of a greater number of options for medical therapy. Hence, for many patients, medical treatment of $\mathrm{GH}$ excess will be open ended, making tolerability and convenience of administration and cost of great importance when choosing long-term treatment.

Together, with the self-evident advantages of cost and convenience of administration, we have taken all of the above experience to indicate that a trial of cabergoline therapy is reasonable in all patients with active acromegaly following attempted adenomectomy or in those unfit/unwilling to undergo surgery. This report constitutes our audited clinical experience in 15 consecutive patients. Complete biochemical control (judged by a mean serum $\mathrm{GH}<5 \mathrm{mIU} / \mathrm{l}$ and a normal age-adjusted IGF1 level) was achieved in $28 \%$ of patients. Substantial reductions in serum IGF1 were observed in the majority of patients, with 5 out of the 15 (33\%) achieving normality and a further 5 patients demonstrating a clinically useful reduction on treatment.

None of our patients had a serum IGF1 > $750 \mathrm{ng} / \mathrm{ml}$ prior to cabergoline therapy; this is likely to represent partially successful surgical debulking in those patients with very severe disease at diagnosis. While this may suggest that the success rate may be lower in an unbiased population, it is interesting to note that of our three patients with a starting IGF1 level $>700 \mathrm{ng} / \mathrm{ml}$, one achieved a reduction of $81 \%$ (Table 2), suggesting that the effectiveness of cabergoline is not confined solely to those with mild disease.

The value of associated hyperprolactinaemia in predicting responsiveness to cabergoline has been conflicting. In the largest reported experience, hyperprolactinaemia was associated with a more favourable biochemical response (14). While our cohort has considerably fewer patients, this effect was not consistently detected in the two patients with confirmed hyperprolactinaemia and positive immunostaining for prolactin on histological review and the patient with the greatest reduction in serum IGF1 did not have hyperprolactinaemia. Our experience would suggest that a trial of cabergoline should not be confined to those patients with coexistent prolactin secretion.

As in previous reports, cabergoline was well tolerated in our cohort. All patients were advised to medicate in the middle of a large meal in order to limit side effects; only 1 out of the 15 patients experienced nausea and this, together with a poor clinical response, led to its discontinuation. Although greater than those typically required for the treatment of lactotroph tumours, the doses of cabergoline reported here are substantially less 
than those used for the treatment of Parkinson's disease and for which recent studies have identified a risk of developing cardiac valvular fibrodysplasia. This effect is thought to be specific to $5 \mathrm{HT}_{2 \mathrm{~B}}$ agonists such as cabergoline and pergolide, and appears to be dependent on cumulative dose. A daily dose of $3 \mathrm{mg} /$ day taken for longer than 6 months has been associated with a significantly increased risk (23). Although at present there have been no reported cases of valvular regurgitation in patients treated with cabergoline for hyperprolactinaemia or acromegaly, and the doses used in these conditions are less than one-sixth of the stated at risk dose, there remains a theoretical risk. Until further evidence regarding the risks of using long term, low dose cabergoline is known it is prudent to use the lowest dose necessary to achieve suppression of GH activity.

In summary, this prospective audit of clinical practice has demonstrated that cabergoline is a well-tolerated treatment for acromegaly and clinical responses have been detected even with modest doses. It provides an easily administered, inexpensive therapeutic tool that may be used as primary or adjunctive therapy for the management of acromegaly.

\section{Declaration of interest}

The authors declare that there is no conflict of interest that would prejudice the impartiality of this scientific work.

\section{Funding}

This research did not receive any specific grant from any funding agency in the public, commercial or not-for-profit sector.

\section{References}

1 Wright AD, Hill DM, Lowy C \& Fraser TR. Mortality in acromegaly. Quarterly Journal of Medicine 197039 1-16.

2 Alexander L, Appleton D, Hall R, Ross WM \& Wilkinson R. Epidemiology of acromegaly in the Newcastle region. Clinical Endocrinology 198012 71-79.

3 Bates AS, Van't Hoff W, Jones JM \& Clayton RN. An audit of outcome of treatment in acromegaly. Quarterly Journal of Medicine $199386293-299$.

4 Fahlbusch R, Honegger J \& Buchfelder M. Surgical management of acromegaly. Endocrinology and Metabolism Clinics of North America $199221669-692$.

5 Swearingen B, Barker FG II, Katznelson L, Biller BM, Grinspoon S, Klibanski A, Moayeri N, Black PM \& Zervas NT. Long-term mortality after transsphenoidal surgery and adjunctive therapy for acromegaly. Journal of Clinical Endocrinology and Metabolism 1998 83 3419-3426.

6 Freda PU, Wardlaw SL \& Post KD. Long-term endocrinological follow-up evaluation in 115 patients who underwent transsphenoidal surgery for acromegaly. Journal of Neurosurgery $1998 \mathbf{8 9}$ 353-358.

7 Sheaves R, Jenkins P, Blackburn P, Huneidi AH, Afshar F, Medbak S, Grossman AB, Besser GM \& Wass JA. Outcome of transsphenoidal surgery for acromegaly using strict criteria for surgical cure. Clinical Endocrinology 199645 407-413.

8 Long H, Beauregard H, Somma M, Comtois R, Serri O \& Hardy J. Surgical outcome after repeated transsphenoidal surgery in acromegaly. Journal of Neurosurgery $1996 \mathbf{8 5} 239-247$.
9 Plowman PN. Radiotherapy for pituitary tumours. Baillière's Clinical Endocrinology and Metabolism 1995 9 407-420.

10 Verhelst JA, Pedroncelli AM, Abs R, Montini M, Vandeweghe MV, Albani G, Maiter D, Pagani MD, Legros JJ, Gianola D, Bex M, Poppe K, Mockel J \& Pagani G. Slow-release lanreotide in the treatment of acromegaly: a study in 66 patients. European Journal of Endocrinology 2000143 577-584.

11 Chanson P, Leselbaum A, Blumberg J \& Schaison G. Efficacy and tolerability of the long-acting somatostatin analog lanreotide in acromegaly. A 12-month multicenter study of 58 acromegalic patients. French Multicenter Study Group on Lanreotide in acromegaly. Pituitary 20002 269-276.

12 Trainer PJ, Drake WM, Katznelson L, Freda PU, Herman-Bonert V, van der Lely AJ, Dimaraki EV, Stewart PM, Friend KE, Vance ML, Besser GM, Scarlett JA, Thorner MO, Parkinson C, Klibanski A, Powell JS, Barkan AL, Sheppard MC, Malsonado M, Rose DR, Clemmons DR, Johannsson G, Bengtsson BA, Stavrou S, Kleinberg DL, Cook DM, Phillips LS, Bidlingmaier M, Strasburger CJ, Hackett S, Zib K, Bennett WF \& Davis RJ. Treatment of acromegaly with the growth hormone-receptor antagonist pegvisomant. New England Journal of Medicine 2000 342 1171-1177.

13 van der Lely AJ, Hutson RK, Trainer PJ, Besser GM, Barkan AL, Katznelson L, Klibanski A, Herman-Bonert V, Melmed S, Vance ML, Freda PU, Stewart PM, Friend KE, Clemmons DR, Johannsson G, Stavrou S, Cook DM, Phillips LS, Strasburger CJ, Hackett S, Zib KA, Davis RJ, Scarlett JA \& Thorner MO. Long-term treatment of acromegaly with pegvisomant, a growth hormone receptor antagonist. Lancet 2001358 1754-1759.

14 Abs R, Verhelst J, Maiter D, Van Acker K, Nobels F, Coolens JL, Mahler C \& Beckers A. Cabergoline in the treatment of acromegaly: a study in 64 patients. Journal of Clinical Endocrinology and Metabolism 199883 374-378.

15 Alexopoulou O, Bex M, Abs R, T'sjoen G, Vellieniers B \& Maiter D. Divergence between growth hormone and insulin-like growth factor-I concentrations in the follow-up of acromegaly. Journal of Clinical Endocrinology and Metabolism 200893 1324-1330.

16 Thorner MO, Chait A, Aitken M, Benker G, Bloom SR, Mortimer CH, Sanders P, Mason AS \& Besser GM. Bromocriptine treatment of acromegaly. BMJ 19751 299-303.

17 Cozzi R, Attanasio R, Lodrini S \& Lasio G. Cabergoline addition to depot somatostatin analogues in resistant acromegalic patients: efficacy and lack of predictive value of prolactin status. Clinical Endocrinology 200461 209-215.

18 Colao A, Ferone D, Marzullo P, Di Sarno A, Cerbone G, Sarnacchiaro F, Cirillo S, Merola B \& Lomardi G. Effect of different dopaminergic agents in the treatment of acromegaly. Journal of Clinical Endocrinology and Metabolism 199782 518-523.

19 Ferrari CI, Abs R, Bevan JS, Brabant G, Ciccarelli E,, Motta T, Mucci M, Muratori M, Musatti L, Verbessem G \& Scarlon MF. Treatment of macroprolactinoma with cabergoline: a study of 85 patients. Clinical Endocrinology 199746 409-413.

20 Jackson SN, Fowler J \& Howlett TA. Cabergoline treatment of acromegaly: a preliminary dose finding study. Clinical Endocrinology 199746 745-749.

21 Selvarajah D, Webster J, Ross R \& Newell-Price J. Effectiveness of adding dopamine agonist therapy to long-acting somatostatin analogues in the management of acromegaly. European Journal of Endocrinology 2005152 569-574.

22 Gatta B, Hau DH, Catargi B, Roger P \& Tabarin A. Re-evaluation of the efficacy of the association of cabergoline to somatostatin analogues in acromegalic patients. Clinical Endocrinology 200563 $477-478$.

23 Schade R, Andersohn F, Suissa S, Haverkamp W \& Garbe E. Dopamine agonists and the risk of cardiac-valve regurgitation. New England Journal of Medicine 2007356 29-38.

Received 1 July 2008

Accepted 29 July 2008 